\title{
Succession of Dung Beetles (Scarabaeinae: Coleoptera) in the Cow Dung Pats of a Tropical Agro habitat in Kerala, South India
}

\author{
Anu Anto ${ }^{1}$, Vinod $\mathrm{K} \mathrm{V}^{2}$ \\ ${ }^{1}$ (Department Of Zoology, St.Xavier's College For Women, Aluva, Kerala, India) \\ ${ }^{2}$ (Department Of Zoology, Nirmala College, Muvattupuzha,Kerala, India)
}

\begin{abstract}
Dung beetles are coprophagous beetles belonging to the order Coleoptera, in the Scarabaeidae family. This study aims to find out the dung beetles species associated with various stages of cow dung decomposition in an agrohabitat.2-6 hr old fresh cow dung pats were placed in open agricultural fields in Kerala, South India. Beetle composition from 8 stages of colonization, lasting 14 days were analysed to throw light into succession of dung beetles. Dung beetles in cow dung pats involved a short stay of 14 days. Fifteen dung beetle species representing eight genera and four tribes were recorded. Both abundance and species richness increased till 4th day of succession and declined beyond. Dwellers were early to arrive, tunnelers were the most prominent guild and rollers were completely absent in the samples. As these beetles plays an important role as ecological indicators, declining population of dung beetles in agricultural habitats, should be taken seriously and more research is needed in this regard.
\end{abstract}

Keywords: Agro habitat, Dung Beetles, Kerala, South India, Succession

\section{Introduction}

India has the largest cattle inventory in the world and the estimated dung production for cattle is 4.5 $\mathrm{kg} / \mathrm{head} / \mathrm{day}$ [1]. Dung beetles in the insect family Scarabaeidae is considered to have the potential to transform this pollutant into nutrient resources [2]. They exhibit many forms of nesting behaviour, including dwelling (endocoprid), rolling (telecoprid), and tunneling (paracoprid) [3]. Soil is perhaps the most important factor influencing the local distribution of dung scarabs [4]. Since dung pats can be extremely patchy in space and time, resource partitioning and competition are prime features of dung beetle species assemblages [5]. Decline of dung beetles in urban and cropland mosaic of Haryana in Northern India [6], made it imperative to look into our agricultural practices. Dung beetles can act as indicator species for habitat disturbance as they respond rapidly to environmental change by showing variations in their community structure, abundance and diversity [7-10]. Understanding more about the ecology of dung beetle communities of agroecosystems, is important not only to further our knowledge of dung beetles, but also in realising the role of herbivorous mammals and their dung in maintaining the below ground diversity at a regional scale. Though, tropical warm moist weather conditions are ideal for the survival of dung beetles which result in high diversity of dung beetles not much scientifically monitored studies have been done in succession of dung beetles in the cow dung pats in the agroecosystems of India.This study is an attempt to show the pattern of succession by various guilds of dung beetles in the degradation of cow dung pat which is regarded as a very patchy resource in the study habitat, due to the rapid urbanization of the area.

\section{Materials And Methods}

The experimental studies to quantify the effects of coprophagous beetles on dung decomposition were set up in open agricultural fields in Kerala $\left(10^{0} 00^{\prime} \mathrm{N} \& 76^{0} 15^{\prime} \mathrm{E}\right)$ during the post monsoon months from December 2014 to May 2015. Vegetation of the area consists predominantly of rubber, coconut and cocoa plantations with intervening grasslands used for cattle grazing. Annual temperature of the area ranged from $24^{0}$ $35^{\circ} \mathrm{C}$ and relative humidity from $65-80 \% .2-6 \mathrm{hr}$ old fresh cow dung pats were collected from the study habitat. To limit the bias arising from the influence of patch size on the dung beetle communities, pats of approximately equal size were used [11,12]. 16 pots comprising three replicates were set up in the field. All the pots were exposed to natural field conditions. Dung were collected in individual plastic bags at intervals of 1,2, 3, 4,5,6, 7, 14 days from the date of defecation. Beetles were sorted by floatation method [13]. Collected beetles were identified to species level with Arrow [14] and Balthasar 15,16]. Data from 8 stages of colonization, lasting 14 days were available for the study. Mean of data from three dung pats were treated as single sample.

\section{Results And Discussion}

Fifteen dung beetle species representing eight genera and four tribes were recorded from cow dung pats during various stages of succession (TABLE 1). Succession of dung beetles in cow dung pats involved a short stay of 14 days. Both abundance and species richness increased till 4th day of succession and declined beyond 
(Fig. 1 a \& b). The size of a beetle species will also determine the amount of dung that it buries. In this study average size of beetles ranged from $5 \mathrm{~mm}$ to $7 \mathrm{~mm}$ and it was seen that the burrowing activity of tunneler species increase the mixing of mineral soil with organic matter. Abundance of dung beetles were maximum during the fourth day of dung deposition and it decreased afterwards indicating similar results in the studies conducted in the forest regions of Western Ghats too [17]. Stay of dung beetles in the pats were for shorter periods ie. mostly for seven days except for $O$. Quadridentatus and $O$. Furcillifer on the $14^{\text {th }}$ day of succession. Studies conducted in forests of the region showed longer stay in the gaur and elephant dung [17,18], perhaps due to the surface crust formation and moisture retention of dung in more humid forest conditions.

Table 1. Succession pattern of dung beetles in cow dung pats in relation to dung age

\begin{tabular}{|c|c|c|c|c|c|c|c|c|c|c|}
\hline \multirow{2}{*}{$\begin{array}{l}\text { Sl } \\
\text { No. }\end{array}$} & \multirow{2}{*}{ Species } & \multirow{2}{*}{$\begin{array}{l}\text { Nesting } \\
\text { Guild }\end{array}$} & \multicolumn{8}{|c|}{ Dung Age } \\
\hline & & & 1 & 7 & 3 & 4 & 5 & 6 & 7 & 14 \\
\hline 1 & Caccobius indicus Harold & $T$ & 2 & 2 & 2 & 3 & 0 & 0 & 0 & 0 \\
\hline 2 & Copris signatus Walker & $\mathrm{T}$ & 2 & 3 & 3 & 2 & 2 & 0 & 0 & 0 \\
\hline 3 & Copris repertus Walker & $\mathrm{T}$ & 0 & 2 & 0 & 0 & 0 & 0 & 0 & 0 \\
\hline 4 & Copris davisoni Waterhouse & $\mathrm{T}$ & 0 & 2 & 0 & 2 & 2 & 0 & 2 & 0 \\
\hline 5 & Liatongus indicus Arrow & $\mathrm{D}$ & 3 & 3 & 3 & 2 & 0 & 0 & 0 & 0 \\
\hline 6 & Drepanocerus setosus Arrow & $\mathrm{D}$ & 3 & 2 & 4 & 4 & 2 & 0 & 0 & 0 \\
\hline 7 & Oniticellus sinctus Fabricius & $\mathrm{D}$ & 1 & 0 & 0 & 2 & 0 & 0 & 0 & 0 \\
\hline 8 & Onitis virens Lansberge & $\mathrm{T}$ & 0 & 2 & 2 & 2 & 0 & 0 & 0 & 0 \\
\hline 9 & $\begin{array}{l}\text { Onthophagus bifasciatus } \\
\text { Fabricius }\end{array}$ & $\mathrm{T}$ & 0 & 0 & 3 & 2 & 0 & 2 & 0 & 0 \\
\hline 10 & $\begin{array}{l}\text { Onthophagus quadridentatus } \\
\text { Fabricius }\end{array}$ & $\mathrm{T}$ & 0 & 2 & 0 & 3 & 0 & 0 & 2 & 1 \\
\hline 11 & Onthophagus falsus Gillet & $\mathrm{T}$ & 3 & 2 & 0 & 0 & 0 & 0 & 0 & 0 \\
\hline 12 & Onthophagus furcillifer Bates & $\mathrm{T}$ & 3 & 0 & 4 & 4 & 0 & 0 & 1 & 1 \\
\hline 13 & $\begin{array}{l}\text { Onthophagus ensifer } \\
\text { Boucomont }\end{array}$ & $\mathrm{T}$ & 2 & 0 & 0 & 2 & 2 & 2 & 0 & 0 \\
\hline 14 & Onthophagus negligens Walker & $\mathrm{T}$ & 2 & 2 & 0 & 0 & 2 & 2 & 0 & 0 \\
\hline 15 & Tiniocellus spinipes Roth & $\mathrm{T}$ & 0 & 2 & 0 & 0 & 0 & 0 & 0 & 0 \\
\hline & Abundance & & 21 & 24 & 21 & 28 & 10 & 6 & 5 & 2 \\
\hline & Species richness & & 9 & 11 & 7 & 11 & 5 & 3 & 3 & 2 \\
\hline & Abundance of tunnelers & & 14 & 19 & 14 & 20 & 8 & 6 & 5 & 2 \\
\hline & Abundance of dwellers & & 7 & 5 & 7 & 8 & 2 & 0 & 0 & 0 \\
\hline & Abundance of rollers & & 0 & 0 & 0 & 0 & 0 & 0 & 0 & 0 \\
\hline & pecies richness of tunnelers & & 6 & 9 & 5 & 8 & 4 & 3 & 3 & 2 \\
\hline & Species richness of dwellers & & 3 & 2 & 2 & 3 & 1 & 0 & 0 & 0 \\
\hline & Species richness of rollers & & 0 & 0 & 0 & 0 & 0 & 0 & 0 & 0 \\
\hline
\end{tabular}

D- dweller, T- tunneler

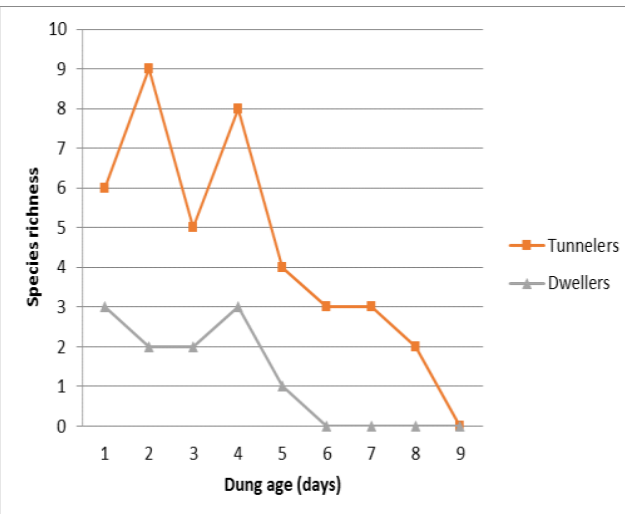

(a)

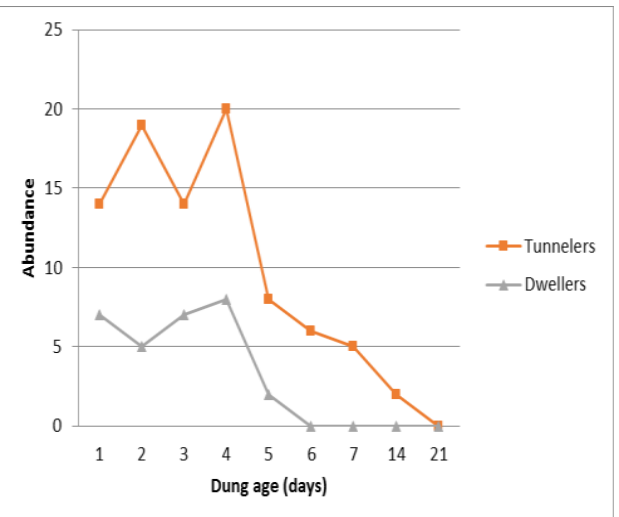

(b)

Figure 1. (a) Species richness and (b) abundance of dung beetle with increase in time of deposition of dung

Dominance of dwellers, Drepanocerus setosus and Liatongus indicus during the initial days of succession in dung pats, indicates their high abundance in the region. Interference from late arriving tunnelers 
leads to decline in the abundance of Drepanocerus setosus from 4th day onwards. Usually dwellers form major part of the coprocenoses in temperate regions and play an insignificant role in Afrotropical coprocenoses $[5,19,20]$ and are outnumbered by the competitively superior rollers in dung pats $[21,22]$ whereas in this study habitat a contrary situation is noted in tropical habitat $[17,18]$.Onthophagus furcillifer, Copris signatus and Liatongus indicus were the other dominant ones. Onitis virens, Onthophagus bifasciatus and Onthophagus quadridentatus were attracted to the dung pats from $2^{\text {nd }}$ day onwards. Nine species arrived in dung pats on first day, five on $2^{\text {nd }}$ day and one on the $3^{\text {rd }}$ day (TABLE 2). Dung moisture content decreased with progressing dung exposure time.

Table 2. Succession pattern of dung beetles associated with cow dung from the study habitat.

\begin{tabular}{|c|c|c|c|c|c|c|c|c|c|}
\hline Sl No. & Species & & & & Dun & & & & \\
\hline & & 1 & 2 & 3 & 4 & 5 & 6 & 7 & 14 \\
\hline 1 & Caccobius indicus Harold & & & & & & & & \\
\hline 2 & Copris signatus Walker & & & & & & & & \\
\hline 3 & Copris repertus Walker & & & & & & & & \\
\hline 4 & Copris davisoni Waterhouse & & & & & & & & \\
\hline 5 & Liatongus indicus Arrow & & & & & & & & \\
\hline 6 & Drepanocerus setosus Arrow & & & & & & & & \\
\hline 7 & Oniticellus sinctus Fabricius & & & & & & & & \\
\hline 8 & Onitis virens Lansberge & & & & & & & & \\
\hline 9 & Onthophagus bifasciatus Fabricius & & & & & & & & \\
\hline 10 & $\begin{array}{l}\text { Onthophagus quadridentatus } \\
\text { Fabricius }\end{array}$ & & & & & & & & \\
\hline 11 & Onthophagus falsus Gillet & & & & & & & & \\
\hline 12 & Onthophagus furcillifer Bates & & & & & & & & \\
\hline 13 & Onthophagus ensifer Boucomont & & & & & & & & \\
\hline 14 & Onthophagus negligens Walker & & & & & & & & \\
\hline 15 & Tiniocellus spinipes Roth & & & & & & & & \\
\hline
\end{tabular}

Dwellers were early to arrive in the dung pat but as the age of the dung increased, their richness and abundance decreased and they were completely absent from the sixth day onwards. Tunnelers were present till the $14^{\text {th }}$ day of dung exposure. Tunnelers were the most prominent guild (richness wise $78.4 \%$ and abundance wise $75.21 \%$ ) and were present during all stages of succession. Rollers were completely absent in the samples collected. As the dung ages, guild wise abundance and richness of the two guilds and the entire assemblage declined. While all three beetle types contribute to dung removal and subsequent agriculture ecosystem benefits, tunnelers probably contribute the most due to the excavating activity and sheer abundance. Though dwellers were early to arrive at the food source, tunnelers were abundant in the dung pat in the late stages and they form the dominant functional guild in the dung pat. Bang et al. [23] has noted that the soil permeability can be increased with tunneling beetles in the top $10 \mathrm{~cm}$ of soil. Rollers were completely absent in the study, indicating their low abundance in the region, which requires further sampling experiments to prove this hypothesis.

When dung was freely exposed to dung beetles, the dung weight decreased rapidly during the first seven days in all dung samples. On the seventh day, several holes on the surface of dung and buried brood balls in the soil were observed. When dung was freely exposed to dung beetles $75 \%$ of the organic matter was found to be removed. It was observed that in these agricultural habitats, dung beetles proves to be effective in the removal of dung from the habitats thus preventing the colonization of flies, maggots etc.

\section{IV. conclusion}

Dung beetle succession study in the agricultural ecosystem showed the dominance of dwellers but the beetle richness was low when compared to studies in tropical forest ecosystems. In agricultural ecosystems the reduction of coprophagous beetle populations most likely has cascading and long-term effects throughout the ecosystem. Management practices that increase the efficiency of nutrient use and cycling on agricultural land are essential for the future profitability from these lands. In this scenario, it is good to look into efficiency of naturally available dung recycling organisms and how important they are in maintaining or increasing the soil fertility of natural ecosystems. 


\section{Acknowledgements}

Thanks to University grants Commission, Delhi, India grant number MRP(S)-0841/1314/KLMG043/UGC-SWRO and Kerala State Council for Science, Technology and Environment with grant no. 1086/2015/KSCSTE for providing financial assistance to the project. Thanks to Ms. Sony George for assisting in the collection of dung beetles.

\section{References}

[1]. N.H. Ravindranath, H.I. Somashekar, M.S. Nagaraja, P. Sudha, G. Sangeetha, S.C. Bhattacharya, and A.P. Salam, Assessment of sustainable non-plantation biomass resources potential for energy in India. Biomass and Bioenergy, 29(3),2005, 178-190.

[2]. G.T. Fincher, The potential value of dung beetles in pasture ecosystems. Journal of the Georgia Entomological Society, 16(3),1981,16-333.

[3]. G. Halffter and W.D. Edmonds, The nesting behavior of dung beetles (Scarabaeinae): an ecological and evolutive approach. Institu' to de Ecologi'a, Me'xico, D. F Publ. no. 10,1982.

[4]. G. Halffter and E.G. Matthews, The natural history of dung beetles of the subfamily Scarabaeinae (Coleoptera: Scarabaeidae). Folia Entomologica Mexicana, 12-14,1966: 1-312.

[5]. I. Hanski, The dung insect community.in: I. Hanski and Y. Cambefort (Ed.), Dung beetle ecology, (New Jersey:Princeton University Press, 1991).

[6]. I.C. Mittal, Diversity and conservation status of dung beetles. Bulletin of the National Institute of Ecology, 15,2005,43-51.

[7]. A Botes, M.A. McGeoch and B.J van Rensburg, Elephant- and human-induced changes to dung beetle (Coleoptera: Scarabaeidae) assemblages in the Maputaland Centre of Endemism. Biological Conservation, 130,2006, 573 -583.

[8]. A.J. Davis, J.D. Holloway, H. Huijbregts, A.H. Kirk-Spriggs and S.L. Sutton, Dung beetles as indicators of change in the forests of northern Borneo. Journal of Applied Ecology, 38,2001, 593-616.

[9]. H.F. Howden and V.G. Nealis, Effects of clearing in a tropical rain forest on the composition of the coprophagous scarab beetle fauna (Coleoptera). Biotropica, 7,1975, 77-83.

[10]. B.C. Klein, 1989 Effects of forest fragmentation on dung and carrion beetle communities in Central Amazonia. Ecology,70,1989, $1715-1725$.

[11]. P. Holter, Resource utilization and local coexistence in a guild of scarabaeid dung beetles (Aphodius spp.). Oikos, 39, 1982, 213227.

[12]. I. Moore, An efficient method of collecting dung beetles. Pan-Pacific Entomologist, 30,1954, 208

[13]. G.J. Arrow, The Fauna of British India including Ceylon and Burma, Coleoptera: Lamellicornia (Coprinae). (Taylor and Francis. London,1931)

[14]. V. Balthasar, Monographic der Scarabaeidae und Aphodiidae der Palaearktischen und Orientalischen Region (Coleoptera:Lamellicornia), Verlag der Tschechoslowakischen Akademie der Wissenschaften. Prag, 1,1963,391.

[15]. V. Balthasar, Monographic der Scarabaeidae und Aphodiidae der Palaearktischen und Orientalischen Region (Coleoptera: Lamellicornia), Verlag der Tschechoslowakischen Akademie der Wissenschaften. Prag. 2,1963, 627.

[16]. T.K. Sabu, K.V. Vinod and P.J. Vineesh, Succession of dung beetles (Scarabaeinae: Coleoptera) in the dung pats of gaur, Bos gaurus H. Smith (Artiodactyla: Bovidae), from the moist deciduous forests of southern Western Ghats. Biosystematica, 1(1),2007, 59-69.

[17]. T.K. Sabu, K.V. Vinod and P.J. Vineesh, Guild structure, diversity and succession of dung beetles associated with Indian elephant dung in South Western Ghats forests. Journal of Insect Science 6,2006,17.

[18]. Y. Cambefort, Dung beetles in tropical savannas, in I. Hanski and Y. Cambefort (Ed.), Dung beetle ecology, (New Jersey:Princeton University Press,1991).

[19]. J.P. Lumaret, and A.A. Krick, South temperate dung beetles, in I. Hanski and Y. Cambefort (Ed.), Dung beetle ecology, (New Jersey:Princeton University Press, 1991).

[20]. B.M. Doube, 1991. Dung beetles of South Africa, in I. Hanski and Y. Cambefort (Ed.), Dung beetle ecology, (New Jersey:Princeton University Press,1991).

[21]. F.T. Krell, S.K. Westerwalbesloh, I. Weib, P. Eggleton and K.E. Linsenmair, Spatial separation of Afrotropical dung beetle guilds: a trade-off between competitive superiority and energetic constraints (Coleoptera: Scarabaeidae). Ecography, 26,2003,210-222.

[22]. H.S. Bang, J.H. Lee, O.S. Kwon, Y.E. Na, Y.S. Jang and W.H. Kim, 2005. Effects of paracoprid dung beetles (Coleoptera: Scarabaeidae) on the growth of pasture herbage and on the underlying soil. Applied Soil Ecology, 29,2005, 165-171.

[23]. T. Larsen, N. Williams, C. Kremen, 2005. Extinction order and altered community structure rapidly disrupt ecosystem functioning. Ecology Letters, 8,2005, 538-547. 